\title{
A vibrant European labor market with full employment
}

\author{
Jo Ritzen ${ }^{1 *}$ and Klaus F Zimmermann ${ }^{2}$
}

\footnotetext{
* Correspondence: Ritzen@iza.org ${ }^{1}$ Maastricht University, VEF and IZA, Maastricht, Netherlands Full list of author information is available at the end of the article
}

\begin{abstract}
We sketch a visionary strategy for Europe in which full employment is quickly regained by 2020, income inequality is reduced and the economies are more sustainable. We call this scenario "vibrant". It is contrasted with what would happen if present policies continue within the European Union (EU) and its member states. In the vibrant scenario, full employment is regained through more policy attention toward innovation and its underlying research and development (R\&D), accompanied by more labor mobility within and between EU countries, in combination with a selective immigration policy based on labor market shortages. The road to full employment is embedded in a landscape with less income inequality and more "greening" of EU member states' economies. We translate the vibrant scenario into policy proposals distinguishing between the role for the EU and that of the member states. We hope these proposals will affect the debate about the future of the European Union, also with regard to the pivotal role and responsibility of the European Parliament and European Commission.

JEL codes: D31, D33, F55, I23, I24, I25, I28, J11, J18, J21, J31, J64, J83, O31, O38, O52

Keywords: Employment; Labor mobility; Innovation; Income inequality; Competition; Labor markets; Greening; Happiness
\end{abstract}

\section{Introduction}

\subsection{The need for a vibrant scenario}

Europe appears to be unable to respond to the financial crisis. In many EU countries, real incomes are decreasing while unemployment as well as income inequality are rising. The EU countries which embraced the common currency are doing worse than those which decided to not adopt it, even though one could make the case that their plight could be even greater without the euro. Full employment-an important policy goal for many European member states-is far out of sight.

The EU has been reacting swiftly and energetically to the economic crisis. It has done so with umbrella funding for countries in danger of a default, proposals for a banking union as well as the completion of linking the monetary union with an economic one; the latter is proposed with measures to ensure the stability pact's implementation in order to keep government budget deficits and debt in check. The "semester" process has been accepted by the member states, implying that they must have EU approval for their national budgets before submitting them to their national Parliament. The "semester" process also implies that the EU delivers country-specific 
recommendations (CSRs) to the member states on how to restructure their economies; for example, they could address research and innovation or labor market regulations.

Still we characterize the present policy approach as "muddling through", which lacks the vision and energy to engage in a more promising future with quickly-attainable full employment. The "muddling through" scenario implies that we not only feel unable to regain full employment but also unable to increase innovation in our economies, counter income disequalization in the EU member states, as well as further green the economies in such a way that our children and grandchildren would also benefit from the resources and climate which Earth provides.

The Vibrant Europe Forum 2012 developed a vision of vibrancy which cherishes and supports entrepreneurship, curbs and avoids excessive inequality, places learning, training and education as a central part of our lives, as well as applies the word "sustainability" not solely as environmental threats but also to how we do business and organize our finances. Here we translate this idea into a scenario which holds the promise to lead to full employment before or in 2020. We focus on labor reforms without claiming that other issues like macro policies are unimportant.

First in Chapter 2, we characterize the European labor market in the period 20002010 when almost full employment was achieved in 2007/2008 yet subsequently unraveled. We use the following lines of inquiry for the scenarios ("muddling through" versus "vibrant"):

- Innovation

- Changes in the production structure

- Employment protection and minimum wage legislation

- Sustainability

- Happiness

Chapter 3 explores the period 2010-2020 as far as the labor market is concerned, on the basis of questions of economic growth, (un)employment, income inequality and greening. With rising unemployment, the first four years of this decade have not been happy ones. The predictions for the rest of this decade tell that employment demand will gradually grow and be sufficient enough to absorb supply, so that unemployment by 2020 would not exceed 5-10\% (Cedefop 2010). However compared to the non-crisis scenario, some 90 million working years are lost (or some 90 million unemployment years are experienced). Income inequality will continue to rise in the muddling through scenario.

Section by section in Chapter 3, we consider the alternatives which a vibrant scenario would bring, such as generating higher growth through more innovation and less income inequality by focusing on redistribution policies, more greening and increased labor mobility rather than employment protection. In many respects this alternative follows the ideas of Project Europe 2030 (González 2010), which stood on the shoulders of the Sapir report (2003) and the Lisbon strategy, agreed upon at the European Council Meeting (March 2000). Europe's growth strategy (European Commission 2012) follows these lines yet fails to address labor market and income distribution. We translate this scenario into policy proposals which could affect the development of the mandate for the European Commission in December 2014 after the forthcoming European elections and the European policies of the coming years. 


\section{Europe's unbalanced economic performance Labor demand and supply}

Full employment as a policy goal of most EU member states has been forgotten in many EU countries. Eurostat (2013) reports that the euro area's seasonally-adjusted unemployment rate was 12.2\% in September 2013, while the EU-28 unemployment rate was 11.0\% in the same month; in contrast, in the United States (US) it was 7.2\%. Yet there are huge differences among the member states. The lowest unemployment rates were recorded in Austria (4.9\%), Germany (5.2\%) and Luxembourg (5.9\%), while the highest were in Greece (27.6\%) and Spain (26.6\%). These variations reflect the differences in economic development, including the policy drivers thereof, as we shall further explore.

Europe had been a success story until an abrupt break in 2008 (Gill and Raiser 2012). It was precisely in the early years of the $21^{\text {st }}$ century that full employment was nearly achieved in many EU member states. These achievements were "earned" by economic policy through "third way" reforms which brought economic growth and employment, but also greater within-country income inequality, which had previously been decreasing for a long period.

The turning point occurred when the financial crisis hit in 2008 since Europe, compared to the US, seemed to be less capable of overcoming it. Several European countries were plunged into a sovereign debt crisis, combined with a prolonged recession with double and triple dips (of GDP growth per capita) in several other EU countries, such as the UK and the Netherlands. Table 1 shows the (predicted) real growth rates of the European economies in the period 2012-2015 compared to those of the US and the world average. This documents the faltering growth which has had severe implications for European employment, as Table 2 shows.

The tables not only document that the EU performs worse than the US but also that within the EU, the Euro area fares worse than the non-Euro area countries, largely as a result of the mal-performance of the countries which could only be rescued from a sovereign default due to the European Emergency Fund.

The EU labor force growth over the period 2000-2010 of some 14 million people was almost fully absorbed by a growth in employment (Cedefop 2012, p.8). Job growth was particularly strong in the period 2003-2008, following a stagnant period at the beginning of the century then followed by job losses after 2008.

The (semi-)public sector accounted for more than half of the employment growth in the first decade of the $21^{\text {st }}$ century. The private sector showed strong growth in the distribution and transport sectors, as well as in business and other services. Contrarily, the primary sector, utilities and manufacturing showed substantial job losses. The construction sector grew slightly in the number of jobs (some additional 1 million jobs).

Table 1 Real GDP growth rates (forecasts 2013-2015)

\begin{tabular}{lcccc}
\hline & $\mathbf{2 0 1 2}$ & $\mathbf{2 0 1 3}$ & $\mathbf{2 0 1 4}$ & $\mathbf{2 0 1 5}$ \\
\hline Euro Area & -0.7 & -0.4 & 1.1 & 1.7 \\
EU & -0.4 & 0.0 & 1.4 & 1.9 \\
US & 2.8 & 1.6 & 2.6 & 3.1 \\
World & 3.3 & 3.2 & 4.0 & 4.4 \\
\hline
\end{tabular}

Source: EU Commission Staff, 2013 (p.1). 
Table 2 Unemployment rate (forecasts 2013-2015)

\begin{tabular}{lcccc}
\hline & $\mathbf{2 0 1 2}$ & $\mathbf{2 0 1 3}$ & $\mathbf{2 0 1 4}$ & $\mathbf{2 0 1 5}$ \\
\hline Euro Area & 11.4 & 12.2 & 12.2 & 11.8 \\
EU & 10.5 & 11.1 & 11.0 & 10.7 \\
US & 8.1 & 7.5 & 6.9 & 6.5 \\
\hline
\end{tabular}

Source: EU Commission Staff, 2013 (p.1).

It is important to note the differences in the employment by education level in the public and private sector; we imagine that the public sector in many countries will not expand in the near future following the substantial expansion in the first decade of this century. The public sector is more education-intensive than the private sector, in the sense that the average level of education of those employed in the public sector is higher.

The crisis (as well as the ensuing government cuts) have resulted in today's startling unemployment figures (as of the end of 2013), with their uneven spread around the EU. Equally startling is the lack of migration from high to low unemployment countries in the EU, since government regulations have low migration thresholds.

It is also remarkable that in almost all of the EU member states, unemployment by education level more or less follows overall unemployment; as such, the unemployment level of highly-qualified people is consistently some 4 percentage points below that of middle-trained people, which in turn is some 4 to 5 percentage points below that of low-qualified workers.

\subsection{Innovation}

The last decades have been marked by substantial labor market changes due to existing or emerging firms with new products or production processes "destroying" the position of existing products and processes. Innovation is the source of fresh wealth and may increase net employment (Soete 2013), albeit of a different structure in terms of the types of skills required; this differs both for the production process (highly-qualified, entrepreneurial and problem-solving skills) as for employment arising from the purchasing power of the newly created wealth (non-routine service jobs).

EU countries continue to do well on the global innovation index (jointly published by Cornell University, INSEAD and the World Intellectual Property Organization, 2013): seven of the top ten are Northwestern European countries; the other three are Singapore, Hong Kong and the United States. However, the EU as a whole would presumably rank (far) below the US. Europe's young leading innovators (called "yollies" for short) are as R\&D-intensive as those in the United States. Europe just has a lot fewer yollies (Gill and Raiser 2012: p.16): Europe has shown a generally poor performance in most of the technology-intensive sectors such as the internet, biotechnology, computer software, healthcare equipment and semiconductors.

In the literature on the relation between economic growth and research, the focus is often on private sector research as the basis for innovation, while ignoring public research. Mazzucato (2013) strongly contradicts this through the examples of Google and Apple which could innovate thanks to public research or governments which financed private research. 
Aghion and Howitt (2006) make a convincing argument regarding the importance of institutional variables in converting research (whether public or private) to innovative activities. They point to competition and new entrants as factors that bring about growth through innovation. This supports the inclusion of a variable on the "ease of doing business" in the Coe et al. analysis (2009).

Moving from public research to labor productivity, a process called valorization, many factors seem to play a role, such as:

- Co-publications between industry and academia

- The inclination to apply for patents and the (inter)national organization of patents

- The ease of doing business (World Bank 2013)

- The entrepreneurial culture and the contribution of education to nurture it

- Credit availability

\subsection{Wage inequality, income inequality and social cohesion}

Wage income inequality is rising due to changes in the production structure

Wage inequality increased in Europe in the period 2000-2010 mostly as a result of the long-run changes in the production structure in which non-routine work became increasingly more important, whereas the relevance of routine work decreased. The changes in the production structure are illustrated by the increase in the wage premium of higher education graduates (for all OECD countries for the period 1997-2003) when the supply of graduates increased (Machin and McNally 2007). If the production structure would have remained the same, the increased supply of graduates would have led to lower wages. Tinbergen (1975) captured this as the "race between education and technology", implying skill-biased technological change.

In particular, computers have created the technological change: less-educated and unskilled workers are pushed out of jobs by robotization; thus the demand for routine work decreases since it can be mechanized, outsourced or offshored. At the same time, the demand for non-routine work-how to make the robots-increases (Autor et al. 2003; Acemoglu 2002).

For Europe it is important to recognize that these changes in private sector labor market demand were accompanied by the expansion of the (semi-)public sector, which is far more higher education-intensive than the private sector. This contributed to a market scarcity for higher-educated workers in the private sector, adding to the upward pressure on wages of well-trained workers, while the public sector wages follow the private sector's wage-setting. In other words, the disequalizing wage effect of the technologic change, which enhanced the relative demand for well-trained workers, was enhanced by the expansion of the (semi-)public sector in Europe. It was further enhanced by the emulation on bonuses and top earnings in the private sector.

OECD (2011) and Chusseau et al. (2008) document how increased imports from lowincome countries (including outsourcing) also pushed out routine labor jobs in OECD countries. At the same time, according to these studies, the effect of the rapid rise in the integration of trade and financial markets has hardly impacted the relative shift in labor demand, in favor of highly-skilled workers. 
Wage inequality has also increased in Europe due to the decrease in minimum wages in relation to median wages between the 1980s and 2008 (OECD 2011, p.30). This was a result of decreasing union power, even though the coverage of collective bargaining generally remained rather stable over time. The immigration of low-skilled workers contributes little to rising wage inequality (Heckman et al. 1998).

\section{Income inequality}

The OECD (2011, p.22) reports that income inequality in the 27 OECD countries has risen from 1975 to 2008: real household income at the bottom decile grew by $1.3 \%$ per year while growth in the top decile was some $50 \%$ higher (namely $1.9 \%$ ) because the redistributive impact of taxation and transfers has decreased in the past decades and because of increased inequality in wages and in non-wage incomes.

\section{Social cohesion}

Social cohesion is a notoriously vague concept (Wilkinson 1997), despite all efforts at measurement through social capital (Putnam 2000) or otherwise. At the same time, it is used in practically every major document from EU member states as a major precondition for the functioning of European democracies. In Europe a low level of income inequality is generally viewed as a precondition for social cohesion. This is in contrast to the US, where a high level of income inequality still (irrationally) seems to signal that there is a chance for "every paperboy" to become a millionaire, presumably based on the (false) assumption that intergenerational mobility is larger if income inequality is greater; the OECD (2008, p.213) has shown that intergenerational mobility is greater when income inequality is smaller.

When launching the OECD (2011) report, the OECD Secretary General Angel Gurría, in the context of the impact of increasing income inequalities on social cohesion, said: "The social contract is starting to unravel in many countries."

\subsection{Employment protection, minimum wages and the quality of work}

Employment protection is specified in legislation, collective agreements or individual employment contracts. This is what we call EPL (employment protection legislation), well knowing that in practice EPL depends on the interpretation of rules by courts or tribunals and the effectiveness of enforcement.

The impact of EPL (in all of its different forms) on employment, the duration of unemployment, labor mobility and on firm-specific human capital accumulation has been widely studied. Special attention is often given to differences in employment protection for temporary contracts and for permanent workers. Martin and Scarpetta (2012) provide a critical review of the recent empirical evidence on the links between regulations affecting the hiring and firing of workers, labor reallocation and productivity growth: "The upshot is that employment protection impacts significantly on labor market flows and these flows, in turn, have significant impacts on productivity growth." (p.20) The $\operatorname{OECD}(2009$, p.121) finds that an average of about 3\% of jobs are destroyed in some industries each year, while an equal number of jobs are created in others. Since the corresponding average net employment growth in the business sector was about 1 percentage point, this suggests that reallocation of labor resources across industries is three times as large as net aggregate employment growth. But sizeable net employment changes at the industry level hide much greater churning at the firm level. Within 
industries, they find that each year on average almost $15 \%$ of all job matches were destroyed but were offset by new matches with other firms and/or with other workers within the same industry. This $15 \%$ figure agrees with the overall notion of jobs "existing" for no more than some six years on average, requiring substantial labor mobility.

Employment protection may reduce mobility from declining in growing industries or within firms with disappearing jobs to newly emerging jobs. It may also have negative implications for aggregate economic and labor market outcomes, even though it is likely that workers pay themselves for the costs of labor protection through lower wages (the Lazear hypothesis, confirmed by the empirical evidence of Leonardi and Pica 2013 for Italy).

The negative effects of employment protection on innovation and employment are widely established by Boeri and Garibaldi (2009), Bartelsman et al. (2011) and Murphy et al. (2012).

Since 1980 onwards, this consideration has been the basis for most OECD countries in order to carry out regulatory reforms to "loosen employment protection legislation (EPL) for workers with temporary contracts" (OECD 2011, p.30). The side effect is that firms have engaged in more hiring of temporary contract workers (Draeger and Marx 2013). Loosening protection for temporary workers, while not reducing the protection in permanent contracts, has been tantamount in supporting a two-tiered labor market. It demonstrates a well-protected upper part contrasting the lower base of temporary contracts with little protection; the latter employs the most vulnerable, the least educated and younger workers.

Boeri and Garibaldi (2009) suggest considering unemployment benefits in relation to job protection along iso-welfare curves. The authors point out that flexicurity (high unemployment benefits with low protection) provides the same welfare as EPL in the form of high unemployment protection with low unemployment benefits while flexicurity offers (potentially substantial) benefits to society due to increased mobility.

It is important to recognize the substantial differences in EPL between EU countries, as one can see in Figure 1.

\section{The minimum wage}

In most EU member states, the wage level of workers with low education levels is mostly determined by a general minimum wage per hour for all workers. Germany has been until now one of the exceptions, although there were minimum wages for a large number of sectors organized by unions and employers, as well as some determined by public intervention; however, it plans the introduction of a general minimum wage on January 2015 (Arni et al. 2014). Minimum wage legislation aims at ensuring that a person who works full time is able to sustain himself or herself, as well as a family, with the wage income. The impact of a minimum wage on both income distribution and on employment has been an issue of considerable debate ${ }^{1}$. The key concern is the degree of the employment loss among low-wage workers and the resulting impact on poverty levels. How much unemployment results from the introduction of a minimum wage or a raise thereof mainly depends on the degree to which workers are affected, the size of the wage change for them and the respective labor demand elasticity. Additionally, the spillover effects of an increase in wage costs on output prices might also have an effect through a reduction of general demand. And further people either non-participants or new immigrants may enter the labor force. Minimum wages only reduce poverty 


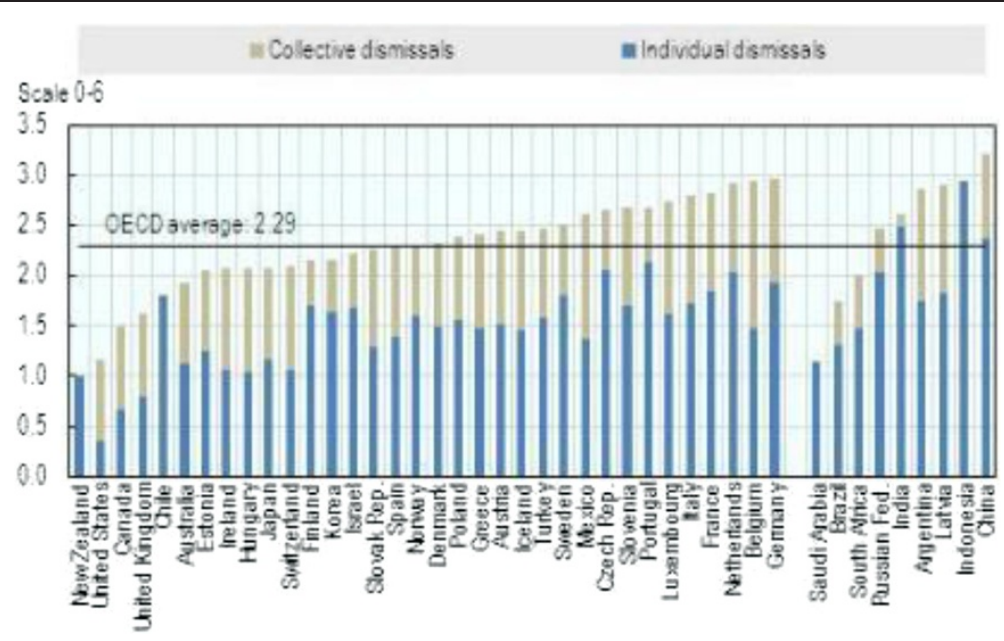

Figure 1 Protection of regular workers against individual and collective dismissals, 2013 (OECD countries). Source: OECD 2013.

among households if workers living in poor households benefit from the minimum wage.

Minimum wages in the EU are often set at such low levels that only a small share of jobs is affected, and the effects on employment are negligible. The minimum wages range from about one euro per hour in Romania and Bulgaria to about 10 euro in France and Luxembourg. It is likely that these minimum wages reduce income inequality while not or hardly affecting employment. Yet high minimum wages may have a serious impact: a recent study by Cahuc et al. (2013) shows that the numerous young people out of work in France, as compared to Germany, is associated with the high French minimum wage. They show that if the French minimum wage were applied to young workers (excluding apprentices) in Germany, then it would affect the majority of young current German workers; 55 percent of young Germans now cost their employer less than the equivalent cost of the minimum wage in France (p.14). At the same time most studies done for the US (for example Teulings 2003) and for the OECD (such as OECD 2011) show that the relative decrease in the minimum wage level-as experienced in many OECD countries over the past decades-is one of the sources but not necessarily one of the causes of increased income inequality. This conclusion is drawn, for instance, without accounting for the positive impact of the decrease in the relative minimum wage on employment. Sabia et al. (2012) show that the 39 percent increase in the New York state minimum wage in 2005-2007 (from the federal rate of $\$ 5.15$ to \$7.15) had "substantial adverse labor demand effects for low-skilled individuals". (p.350) and consequently had a negative effect on the income distribution.

\section{Labor force participation and the retirement age}

Labor force participation rates differ substantially between EU countries mostly due to very different social security and pension regulations. Some countries have moved the retirement age upwards, in alignment with life expectancy and demographic development (with more old-age persons relative to the working population). Others, such as France and Germany, continue to lower the pension age. Replacement rates are also 
substantially different among the EU member states because of differences in benefit systems for the unemployed.

\subsection{Greening}

We use the term "greening" to indicate a process towards sustainability. The vibrant scenario aims at more greening within the European economies. Policies towards more greening, like the German Atomausstieg, affect employment. More greening in a country may lead to higher prices for products and services, making the country less competitive.

The progress-or lack of greening-can be measured by an ecological footprint (how many resources we use in relation to available resources). The ecological footprint represents the amount of biologically productive land and sea area it takes to supply the resources a human consumes and to assimilate associated waste (WWF 2012, p.135). For 2007 it was estimated that humanity as a whole used resources 1.5 times as quickly as Earth can renew.

Expressed in footprint hectares (ha) and bio-capacity per citizen, the range throughout Europe is considerable: Denmark has the largest footprint of 8.3 ha with a biocapacity of 4.8 ha while the smallest is in Romania at 2.8 ha (bio-capacity of 2.3 ha) (WWF 2012, p.144). The EU's average footprint is 4.6 ha with a bio-capacity of 2.2 ha. These footprint data include the carbon footprint, in such a way that the required natural sequestration is estimated to maintain a constant concentration of carbon dioxide (CO2) in the atmosphere. For example, in 2008, one global hectare could absorb the CO2 released by burning approximately 1,450 liters of gasoline (WWF 2012, p.137).

\subsection{Happiness and the labor market}

The socio-economic environment's impact on people's individual well-being has been advanced as a potentially important evaluation criterion for socio-economic policy, as first formulated by Easterlin (1974). A person's enduring level of happiness is an experience brought about by personal factors and important external factors such as income, work, community and governance (corruption, freedom, social support), as well as values and religion.

When people become unemployed, they experience sharp falls in well-being, which remain at this lower level until they are re-employed (Helliwell et al. 2013, p.66). Lalive and Stuetzer (2011, p.21-22) agree, although they find that the impact is somewhat lessened by the level of unemployment benefits.

High unemployment has spillover effects not only on the families of the unemployed, but also on those working since they feel less secure in their jobs. When we sum up the entire loss in well-being of a rise in the unemployment rate, the total is twice as large as the loss to the unemployed themselves, according to Helliwell et al. (2013, p.67).

In other words, one of the most important aspects of the labor market in terms of well-being is whether individuals are able to find a job, given that they want one. This is a clear call for a full employment policy as a "happiness strategy".

\section{Employment and happiness}

For those who are employed, the quality of life at work is important. The trade-off between the level of (macro) employment and the quality of work for those who are employed then needs to be envisaged. 
For the EU, Boeri and Garibaldi (2009) conclude that a permanent contract increases the probability of being satisfied by 7 percentage points from the baseline, while the importance of employment protection for happiness of permanent contract workers decreased between 2000 and 2005 .

Workers' well-being matters not only for themselves but also for firms: it is a good predictor of productivity. It is well-known that workers who are more satisfied with their jobs are less likely to quit; they are also less likely to reduce firm productivity via absenteeism or presenteeism-showing up for work but contributing little (Robertson and Cooper 2011; Cooper and Lundberg 2011).

The bottom line remains one given by Gruen et al. (2010), using the German SocioEconomic Panel:

“...we cannot identify a single job feature or a combination of such features that constitute such low quality jobs that remaining unemployed would be the better choice for the individual. On the contrary, the bulk of our evidence shows that even low quality jobs are associated with higher life satisfaction, and this effect is statistically significant for most specifications of "bad" jobs."

Similarly, a parallel study examines the value of the large German workfare program and concludes that people's life satisfaction rises substantially after moving from being totally out of work to being part of the program (Wulfgramm 2011).

It is likely that national happiness might decrease with a reduction in worker protection for those with permanent contracts. Yet it is equally likely that total happiness increases if the same decrease in worker protection results in increased employment.

From OECD figures Europe appears to have been an overall happy continent in the decade 2000-2010. When asked to rate their general life satisfaction on a scale from 0 to 10, people across the OECD averaged 6.7. Some countries-Hungary, Portugal, Turkey and Greece-have a relatively low level of overall life satisfaction, with average scores of less than 5.5. At the other end of the scale, scores were higher than 7.5 in Denmark, Norway, the Netherlands and Switzerland. There is little difference in life satisfaction levels between men (6.6) and women (6.7) across OECD countries. However, social status strongly influences subjective well-being. The bottom $20 \%$ of the population in OECD countries has a life satisfaction level of 6.1. This score increases to 7.3 for the top $20 \%$.

Unhappiness is concentrated in poorer countries such as in Bulgaria. Not only do absolute happiness levels differ but their variations also differ between countries. Among OECD countries the correlation between country means and standard deviations is significantly negative (more variance when the mean is lower). Among those countries with high average scores, some have quite high degrees of equality in the distribution of happiness (Denmark and the Netherlands), while in some fairly low-ranking countries (Bulgaria and Romania) there is much more dispersion.

OECD countries with higher unemployment levels appear to be less happy, when measured by the level of happiness or the degree of dispersion of happiness (more dispersion with more unemployment). This confirms the micro findings on individual happiness and the individual (un)employment experience. More econometric research is needed to confirm the result of this casual inspection. 


\section{Europe 2010-2020: muddling through or a vibrant alternative}

In this chapter we address the policies of the EU member states leveraged by the EU in order to achieve a vibrant European economy with close to full employment (through more innovation), less income inequality and more greening in the period 2014-2020. We compare this with the status quo scenario, named "muddling through". Muddling through does not include major policy changes. We focus here on the labor market without plunging into the financial or fiscal side. The inadequacy of the EU's monetary and fiscal instruments has been a major reason for its slow recovery, compared to the US, in the post-crisis period (see Tables 1 and 2). These institutions are in the process of repair. In both of our scenarios it is assumed that the financial framework for the Eurozone and the EU as a whole is fixed, meaning that credit flows will resume to precrisis levels and that fiscal consolidation continues to take place.

The labor market for the muddling through scenario is mostly derived from a Cedefop study (2010). These are the only projections available. We consider these projections to be too optimistic with respect to (the resumption of) employment growth and the reduction of unemployment, as they do not appear to depart from fiscal consolidation. Fiscal consolidation in part implies a break away from public sector expansion (health, education and general government services), having substantial implications for employment, in particular for those with higher education. Fiscal consolidation has also been driven by increases in taxes, with their negative employment effects. Lastly, the reduction in transfer payments-included in fiscal consolidation-has reduced spending on consumption with its consequences for employment.

In contrast to muddling through, the vibrant scenario aims to reach full employment within the shortest possible timeframe and maintain it thereafter. Full employment is achieved and maintained through more innovation, greater labor mobility, flexicurity, work-related social security and less labor regulation embedded in policies which generate less income inequality (through restrictions on top wage incomes and focusing on social security). This approach can be argued as contributing to increased happiness, in terms of both level and distribution among the European population.

Labor market policy in the $\mathrm{EU}$ is the responsibility of each member state. At the same time, the EU has the responsibility to deliver country-specific recommendations (CSRs) regarding innovation and labor market policy as part of the semester approach. We shall discuss how member states could more quickly implement these CSRs. The major question is not whether such an alternative is possible. It is about governance: are EU politicians and politicians of the member states, who would agree with the "vibrant" goal of full employment, able to carry it out with the support of their constituencies?

\section{The labor market 2010-2020}

In the period 2008-2013, the EU has experienced a shaky economic development: EU growth rates plummeted and the EU-27 entered a recession (-4.3\% growth in 2009) with a second dip in $2012(-0.4 \%)$. Economies in other parts of the world are growing faster than in the EU, notably in countries that are catching up, like China, India, Brazil and Russia (the BRIC countries), Malaysia, Indonesia, South Korea and Turkey (the MIST countries) and also in the US. 
The labor force will increase less than it did in the previous decade. The shift towards a better-trained labor force continues unabatedly. Yet economic growth remains sluggish while the level of innovation in Europe may be overtaken by countries outside of Europe: Singapore ranks second in the 2013 World Economic Forum innovation index and Hong Kong seventh (up two places from 2012); meanwhile relative indexes worsened for the Netherlands, ranking eighth in 2013 (from fifth in 2012), and the UK (from eighth to tenth, also in 2012 to 2013) (Cornell University, Insead and WIPO 2013).

The Cedefop (2010) predictions-which were computed before the major downturn in employment-show that gradually employment demand should again grow enough to absorb supply, so that unemployment by 2020 would not exceed $5-10 \%$. And even then, compared to the non-crisis scenario, some 90 million job years would be lost.

However, as we said: the Cedefop projections may be (far) too optimistic, because they have not taken austerity measures into account. The first two years in the projections, 2012 and 2013, show mounting unemployment rather than a decrease. In September 2013, the youth unemployment rate in the Eurozone was over 25 percent and still increasing. It exceeded 30 percent in Italy, Portugal and Slovakia, while it was over 57 percent in Greece and Spain. Youth unemployment rates were also high and increasing in reasonably successful countries such as Belgium and Malta.

Unemployment continues to be unevenly spread across the EU. It also remains skewed across education levels. People with low qualifications will continue to find it difficult to obtain a job.

In summary, a continuation of present policies might gradually (in 2014 and thereafter) bring a reduction in EU unemployment. However the road to full employment will be long and is unlikely to be achieved by 2020 .

\section{A vibrant scenario}

A vibrant European labor market with full employment would be first and foremost the result of individual EU member countries' policies, once the stability pact and the Banking Union have been implemented and credit flows resume pre-crisis levels. These fiscal and monetary policies have been belatedly brought to the European level as necessary complements to introducing the euro. Yet for employment and social policy, the responsibilities largely remain with the EU countries' national governments, albeit that the European Commission (2013) wants to strengthen the "social dimension" of the Economic and Monetary Union (EMU) by using employment and social indicators as part of the "European Semester" process for economic policy coordination.

At present, public debts and budget deficits attract the most attention in the Semester process, in which EU member states' governments have to submit their budget proposals first to the EU, before presenting them to their national parliaments. The EU gives binding criteria applied to the levels of government deficits and sovereign debt as in the stability pact for the euro.

The European Parliament (2012) has called for strengthening the EMU with a "social pact", to be included in the Van Rompuy (2012) report, which restricted itself to four pillars of the EU: financial integration, budgetary framework integration, economic policy integration and democratic legitimacy. 
"Fiscal consolidation" is the EU member countries' commitment to comply with the Maastricht criteria in terms of government budget deficits and sovereign debt levels. It is essential in order to avoid a substantial interest claim on government income, pushing out expenditures for education, health, social transfers and the like. Yet if it leads to economic policies in which countries with substantial trade surpluses are inducing wage reductions and slowing down public investment (in infrastructure or in public $R \& D)$, then the single-minded application of fiscal consolidation may not serve its purpose, as it smothers economic growth. Likewise "austerity" should not block needed reforms in the labor market structure, nor in other markets. Vibrancy would start with adopting the policy goal of full employment, as this may serve as a reference point for "smart austerity".

Hence we suggest: Full employment should become an EU goal to be realized by 2020. The new European Parliament should demand an employment proposal from the Commission that would have the potential to regain lasting full employment relatively soon, as well as the implications for the Maastricht criteria and the Semester process. The new European Commission (which starts in December 2020) should have a mandate to engender full employment by 2020 .

The goal of full employment translates into five policies: innovation (3.1), income (3.2), mobility (3.3), immigration (3.4) and greening (3.5).

Aside from an EU-wide agreement on full employment as a policy goal, a social scoreboard might be helpful. This would be done with agreed measurements and objectives and ensure that the EU leverages both economic and social goals in EU countries. Poverty levels and social goals would be recorded next to macroeconomic and employment indicators.

Automatic stabilizers at the EU level could also be a "leveraging" European approach to help individual EU countries reach their economic and social goals. Automatic stabilizers have been amply researched (Peichl et al. 2013), for example in the form a fiscal union or a European unemployment scheme, in which a minimum level of unemployment benefits would come from a European fund for a maximum duration of one year. However, this is a difficult proposition since it involves distributional consequences as well as moral hazards.

Social goals need to be narrowed down to a small set of basic needs with a clear view on full employment as the best social policy. Too much spending on social protection will undermine competitiveness. It is critical to maintain a link between wages and productivity, allowing room for collective bargaining. Keeping this link also means that high-productivity countries should allow wages to increase.

\subsection{Innovation}

Economic growth and employment projections hinge on assumptions regarding innovation and competitiveness. There are few signs that the EU-27 takes the vibrancy challenge seriously (in contrast to the language used in the Lisbon declaration of 2000) as expressed for example by the outlays for research and development or the relative absence of "yollies" in Europe compared to the US. The increased outlays for public $R \& D$ and for the improvement of educational quality in BRIC, many MIST and in the oil-rich Arab countries, has little following in Europe, except for some "excellence 
initiatives" such as the one in Germany (see country reports in Hoareau et al. 2012). It is likely that, on average, European countries will find themselves falling on the Global Innovation Index; instead of six EU countries making the top-ten list in 2013, there may be no more than three or four in 2020.

The Horizon 2020 program (in the EU Framework Programme for Research and Innovation) foresees an EU outlay of some 70 billion euros for the period 2013-2017. The EU Commission (2012) feels that the EU should specialize, as well as compete globally, in green economy, healthcare and information and communications technology (ICT). This H2020 program is a major increase in the European public research effort, even though it constitutes less than $10 \%$ of the total EU budget. In parallel, the agricultural subsidies budget remains at around 50\%, making the EU more about milk and wine, or butter and beef, rather than knowledge. At the same time, many member states have cut their R\&D outlays (Hoareau et al. 2012).

\section{A vibrant scenario}

More public $R \& D$, less entrepreneurial regulation, better quality education and more credit for startups can raise labor productivity in the longer run. However, R\&D outcomes are not only about money; the organization of R\&D plays a major role. It is clear that there are huge differences between EU states regarding the effectiveness of public $R \& D$ expenditures, whether measured in citations, patents, knowledge-based startups, or in "entrepreneurship".

A new convergence in per capita incomes between EU member states could arise from stronger human capital and R\&D positions in the poorer countries. In this respect, it is counterintuitive to notice that structural and cohesion funds-meant to bring about convergence-are hardly allocated toward universities or R\&D, with the exception of Poland (see country reports in Hoareau et al. 2012).

Innovation cannot be enacted by law, nor be taught at school as to how it can be generated, even though entrepreneurship education could have a substantial impact on innovation. Policies should rather be designed to incentivize and enhance an environment for more private innovation. This is concerned with lessening bureaucracy, easing patenting, reducing costs and standardizing treatment of intellectual property rights. European education systems are typically very formal, which is arguably not the best pre-condition for future innovation, since this cannot be taught at school or university. It rather needs an education system that not only allows for but actually encourages creativity from the very beginning of (preschool) education while at the same time explicitly pays attention to entrepreneurship training.

Our following policy recommendations to stimulate innovation (as a means to generate employment) for the EU member states are then:

- Provide more public R\&D closely related to industry

- Increase the ease of doing business (World Bank Doing Business report: ease of doing business index)

- Give more attention to entrepreneurship education at all education levels

- Implement dual education at all education levels (including higher education) after the age of 16

- Provide more (pre)venture capital 
At the EU level, several steps could be taken:

- Ease patenting through a simple European patent to supersede national regulations

- Allocate $50 \%$ of cohesion and structural funds to higher education and public research

The most radical proposal for the EU to leverage individual member states is:

- Allow additional R\&D expenditures in EU countries (above the status quo) to remain outside of the Maastricht criteria

\subsection{Inequality}

The implications of the labor market demand and supply forecasts all point in the direction of an increasing wage-income inequality under the muddling through scenario.

The increased wage inequality will translate to increases in income inequality. Income inequality will be further enhanced in Europe through the following processes:

- Income inequality between European countries will decrease less than in the past as the "convergence machine" seems to have halted; the differences in growth rates between richer and poorer countries seem to be less (OECD 2012), implying that the gap remains between richer and poorer countries.

- Income inequality also increases because of the continued increase in capital income that mainly serves higher incomes.

- The room for more progressive taxation is not considered to be a serious alternative: governments seem to be moving in the direction of a "flat tax".

- The room for inequality reduction through social expenditures is under pressure as a result of the sovereign debt crisis.

As a result it is likely that we will see a worsening of the European Gini coefficient, even more than that of the first decade of the $21^{\text {st }}$ century when it increased by about $5 \%$.

\section{A vibrant scenario}

The vibrant scenario implies more innovation compared to the muddling through scenario. But this also means that the demand for well-trained workers is higher in this scenario, which if anything leads to more wage inequality as a result of the greater bargaining power of well-trained workers.

Wage inequality can be reduced by raising wages at the bottom through increased demand, like expanding the (lagging) demand for low-skilled work by developing the service sector or by creating public jobs for low-skilled workers. Currently large parts are hidden in Europe's shadow economy, estimated to account for up to one-sixth of GDP in Germany alone (Schneider 2003). The Belgian scheme of service checks has been helpful in creating additional demand for low-skilled workers.

Kolev and Saget (2010) address policies to mitigate earnings inequality. Regarding the low-end of the labor market, policies to reduce inequality should target the labor supply, such as providing workers with better skills and training; additionally policies also need to focus on labor demand measures, such as investment in job creation, as well as 
the support for institutions to ameliorate low paid workers' salaries through paths like collective bargaining and minimum wages.

At the upper part of the wage distribution there is room for limiting the rising top earnings, along the lines of the adopted Swiss referendum (of March 2013). This referendum says: no more golden hellos, no more golden parachutes, no more bonuses linked to merging a company with another and a binding vote on executive pay by shareholders. Pension funds holding shares in a company would be obligated to take part in votes on compensation packages. Violations could result in fines equal to up to six years of salary and a prison sentence of up to three years.

A European-wide dialogue with the private sector on maximum wages (excluding the rewards of entrepreneurial work, i.e. risk taking with potential private losses) might bring about such caps on non-entrepreneurial income Europe-wide, avoiding the potential for escape by moving from one EU country to another.

The exodus of top talent by emigration to regions outside of Europe (to the US or Australia) of such a regulation is likely to be minimal, if one can generalize the findings for the US (Young and Varner 2012) for Europe. They conclude that top-income taxes in California do not lead to observable tax flight. They also studied the migration patterns of New Jersey's millionaires before and after 2004, when the state imposed a "millionaire's tax" that raised rates on those earning $\$ 500,000$ or more to $8.97 \%$ from $6.37 \%$ and conclude that "millionaire flight" is a myth. However, Vedder (2003) finds a substantial impact of tax rate increases on out-migration from one US state to another.

Moreover, the vibrant scenario should also look for policies to combine smart growth with a return to a more redistributive tax and transfer policy (Atkinson 2013). Decreases in the bottom income tax rates, or the introduction of a luxury rate of VAT, can contribute to fiscal consolidation and help ensure that the burden of fiscal adjustment can be more fairly shared. The merits of an increase in the income tax top rate are debatable.

Perhaps the impact of a "millionaire's tax" in Europe, if applied Europe-wide, would not lead to substantial emigration. The introduction of a millionaire tax in France in 2012 with a number of high-publicity flight cases will perhaps be a good case study, albeit that this was a tax only for residents in France thus evasion was easy by moving across the border to nearby European countries. Zoutman (2014) argues that top rates are already beyond revenue maximizing.

Limiting top incomes would have a strong impact on income inequality in the uppermost income bracket (top 1\%). At the same time the possible increase in entrepreneurial income and capital income-as may be expected from a more vibrant scenariomay offset the income, reducing the impact of the top income limitation brought about by shareholder constraints.

The incentives to engage in regular work could be found in the workfare principle: there is no financial support without work or commitment to further education (Schneider and Zimmermann 2010). Rinne and Zimmermann (2012) argue that important factors that have recently contributed to the strong German employment resilience have stemmed from the 2003 Hartz market reforms, the extension of short-time work, the behavior of social partners and automatic stabilizers in social security expenditures. The impact of these reforms in Germany seems to have clearly reduced income inequality (Grabka et al. 2012). 
Between country differences should be reduced by helping lower income countries to converge faster with higher income countries. This means de facto that they should quickly switch from imitation to innovation technologies. The policy described above, focusing on cohesion and structural funds for 50\% for R\&D and higher education, might be helpful for such a switch.

Therefore the following are policy recommendations for a vibrant scenario for EU member states:

- Introduce or augment income support for the working poor based on family circumstances through tax credits. If minimum wages are politically necessary they should remain low to avoid the destruction of jobs which require little education.

- Introduce wage subsidies where labor demand is failing and where there is a "social" demand for work which requires less education (e.g. the Belgian example of the service checks or concierges at school).

- Uphold income-related prices for public services, with consideration of the poverty trap.

- Engage in a European-wide dialogue with the private sector on maximum wages (excluding the rewards of entrepreneurial work, i.e. risk taking with potential private losses) to bring about Europe-wide caps on non-entrepreneurial income.

\subsection{Mobility policy}

It is unlikely that the muddling through scenario, even with increased innovation, could reach full employment by 2020 because of (too) low labor mobility within and between EU member states. Existing jobs disappear while new, different jobs appear as the halflife of jobs is decreasing in line with the half-life of products and production technologies. In the process, routine work in particular will continue to disappear due to robotization. If workers do not switch from jobs (in the sense of a given set of tasks) towards newly emerging jobs, either because they are immobile or have not upgraded their skills, then we could enter into a stage with substantial unemployment in combination with a substantial unfulfilled demand for labor. Full employment can only be realized if individual workers feel responsible for their own employability by being mobile and through upgrading their skills. In this respect, employment protection is a misnomer since it cannot protect the worker from non-employability.

\section{A vibrant scenario}

The vibrant scenario is defined as having increased labor mobility within and between EU countries with EU member states at the helm; this would be leveraged by the EU as a knowledge clearing house (on what works and what does not), with country specific recommendations and guidelines.

Increased labor mobility is needed because of the reduced half-life time of products, because of the creative destruction of jobs due to innovation, and because of unemployment differences between industries, regions and countries.

In the vibrant scenario the level of job protection for temporary contracts is increased while that for permanent contracts is reduced. Many different measures are needed. We distinguish between member state and EU policy. 
The member states should focus on increasing mobility within their countries. The general notion is that unemployment should not occur if a job is lost, because workers anticipate the disappearance of the job and timely "hop" to another one. An incentive for anticipation is:

- Reconstruct severance pay in permanent employment in the Austrian way as accumulated savings that can be transferred to another job.

Other incentives are:

- Paid leave during the notice period for the purpose of job seeking (e.g. 5-20 days)

- Sponsorships enabling individuals to try out a new job to see if it suits both parties (trial periods)

- Support while starting a new business (for example, low interest credit)

- Regular training (general and firm-level) for employed individuals to maintain employability, in worker adaptability to both the knowledge economy and technological change; making this a legal right for all labor contracts would be an important counterbalance for less worker protection

- Further improvement of employment service through the provision of information about labor market and training possibilities, training, personal guidance, advice and counseling (on education and career choices), coaching on job search processes, and personal development activities individually or in groups (starting at the moment of the dismissal notice)

- For those who still experience unemployment, EU member states would have "flexicurity" (high benefits for a short search period), including well-functioning employment services

The EU's role in coordination with the member states on mobility policy could be:

- Engage in active policy towards the implementation of country-specific recommendations for the labor market in individual member states, perhaps by discussions on these recommendations between the European Parliament and national parliaments.

- Ease fiscal and monetary constraints (Maastricht criteria) according to an agreed framework for member states that sign up for reform aimed at full employment.

- Improve mobility across European member states by improving language skills (compulsory English as a second language starting at an early age).

- Ensure full integration of intra-EU mobility through migrant language programs.

- Recognize degrees and work experience of other EU countries.

- Create EU-wide pension systems, as proposed by the EU for academics, which are not country-dependent.

\subsection{Jump-starting youth employment}

Muddling through with youth unemployment is an unhealthy option because of the scarring effects of youth unemployment which would still be visible some 20 to 30 years 
later (Boeri 2013). However, solutions for youth unemployment should be embedded into a long-run employment policy aimed at full employment. The youth employment guarantee of the EU bears serious political risks if there is no job at the end of the guarantee period (See Cahuc et al. 2013 for further discussions).

\section{A vibrant scenario}

As an additional measure, one could think to introduce a European social youth loan scheme, for example totaling 50 billion euro for the years 2014 and 2015. The notion would be that every young EU citizen between the age of 20 and 30 could take out a loan for a maximum of 40,000 euro at an interest rate of the government lending rate plus 2\% (for default and administrative costs). It would be a personal loan that would have to be paid back according to social loan schemes. This would be similar to what some EU countries do for education loans. Basically it means one would never have to repay more than $10 \%$ of his or her income; additionally, at some point (after 20 or 25 years) if there is still a remainder of the loan, it would be written off.

The loan would have to be spent in the EU within two years following procurement (any unspent amount would be repaid immediately). It could not to be used to "play the stock market" or to save. At the same time the conditions should not be too strict in order to keep administrative costs as low as possible.

The loans should not lead to contraction of credit available for other purposes. Hence it is assumed that the European Central Bank would accommodate it in the money flow as a focused form of quantitative easing. In this way a monetary impulse is provided in spending while giving young Europeans a chance to start a business, to study, or to invest in his or her own human capital in other ways. The EU policy brief on youth entrepreneurship (2012) shows that $40 \%$ of young Europeans have an interest in starting a firm of their own. A loan scheme as proposed might help to realize this interest.

\subsection{Vibrant immigration}

Immigration is not a popular issue with the average European (Zimmermann 1995). Nonetheless, the EU needs to continue to view immigration from outside the EU for its potential to reduce the emerging shortages of well-trained people, in view of the development of European demographics (Zimmermann 2005). At the same time the EU needs to deal with the pressure for immigration into the EU which now mostly evolves through asylum seeking and refugee admission policy, aside from family reunion. Additionally, significant resources have been mobilized to fight human smuggling and trafficking networks in the EU.

Asylum seeking is one part of recent immigration. It is a highly contested and often a human drama. The great majority of the asylum requests are rejected, yet it is then often difficult for the rejected asylum seeker to return home without documents, which may be lost or nonexistent.

Active labor recruitment is still only a minor part of immigration (slightly higher than the number of those seeking asylum). EU policies encourage labor recruitment, while immigration policy is often focused on two areas: preventing both unauthorized migration as well as illegally employing migrants lacking work permits, and promoting the integration of immigrants into society. 
The EU has begun with a new immigration policy by introducing the Blue Card in 2012, aimed at attracting well-educated workers by granting them the right to work and live in a specific EU country. Also it might be well advised to leave room for immigration into the EU for those who do not satisfy the Blue Card criteria; this can be achieved through a regulated quota system based on labor market needs as an alternative to the "asylum route".

European immigration policy could learn from the Israeli and US experiences, where all immigration is in principle temporary and where permanent status is achieved only after a couple of years. At present, this differs between EU member states.

In summary:

- A more clear-cut and focused immigration policy is needed, while at the same time efforts should be enhanced towards integration, particularly for the second and third generation children at school.

- It is equally important to develop a political base for a labor-market oriented immigration policy.

- A first step would be to expand Blue Card access to the whole European labor market, not just within the arrival country.

- A second step would be to expand the Blue Card to well-educated immigrants, even if they do not have a job offer.

- As a third step, non-European students graduating with a Master's degree or equivalent from (selected) European universities should be automatically eligible for a Blue Card.

- Apply anti-discrimination regulations more strictly.

- Asylum requests are only accepted when filed from outside of Europe (either in the first country after leaving the home country or at European borders).

- Leave room for immigration into the EU for those who do not satisfy the Blue Card criteria, based on a regulated quota system for labor migrants.

- Immigration is in principle temporary; the permanent status is achieved after a couple of years.

\subsection{Sustainability}

There is little leeway for enhanced greening policies in countries with considerable unemployment and faltering economic growth. In the period 2014-2020, no major greening initiatives can realistically be expected under the present growth and employment prospects, despite the obvious need for more greening as a "no-regret" scenario.

Even in countries that successfully overcame the crisis, like Germany, further greening policies are at risk. This is exemplified with the remarkable and daring Atomausstieg in Germany where the closure of their nuclear reactors by 2020 will imply a substantial rise in the price of energy. The decision followed earlier German greening initiatives like the feed-in tariff for locally produced "clean" energy, costing some 17 billion euros in 2010. Both the feed-in tariff and the Atomausstieg have resulted in substantial energy price increases, as well as political backlash.

\section{A vibrant scenario}

Greening (a smaller footprint) raises prices in such a way that goods and services with a larger footprint will have the largest price increase. In this way, a shift in 
consumption is encouraged away from "ungreen" goods and services. The end result is an average price increase for the total basket of consumption goods. Such a price increase would in part mitigate the increase in welfare of this "vibrant scenario" policy package measures, leading to more innovation and higher economic growth.

It is unclear how additional greening efforts could impact the composition of employment. If greening is aligned with innovation, the impact on employment is positive (as is the intention of Atomausstieg).

The increased prices of "ungreen" goods and services might impede European firms' exports and thus impact its international competitiveness. However, this need not be the case if Europe (either by Kyoto-type agreements or WTO negotiations) can create a level playing field. WTO negotiations can help create this if the EU can levy import taxes on "ungreen" goods and services to a level which would adjust the import price to include the added costs the EU bore in order to make its production greener.

\subsection{Happiness}

From the aforementioned points of the impact of income, its distribution and unemployment, it is obvious that Europe's average level of happiness is likely to decrease in the years to come. This is primarily due to the impact of unemployment, both on the unemployed as well as on the employed. At the same time, the happiness distribution across EU member states will greatly vary. This was documented by the OECD (2013a, b) which showed that between 2007 and 2012, average life satisfaction declined by more than $20 \%$ in Greece, $12 \%$ in Spain and $10 \%$ in Italy.

\section{A vibrant scenario}

Some consideration could be given to happiness, which is a function of unemployment (negative relation), EPL (positive relation) and income, in a world with rapidly changing jobs. Overall it can be argued that the vibrant scenario is superior to muddling through as it comes closer to full employment, leads to more growth and less inequality and to more greening, while realizing that there are "happiness costs" involved in reducing employment protection and increasing labor mobility within and between EU countries.

\section{Summary and conclusions}

Fixing the Eurozone's financial framework, as well as the banking sector, is critical in order to reach a level of economic activity which can reduce European unemployment to an acceptable level by 2020. Yet in the meantime, some 90 million job years are lost, while it is unclear if labor productivity will continue to increase at pre-crisis levels, or if economic growth will pick up sufficiently in order to reduce unemployment in the EU at large. This "muddling through" scenario also means that earlier developments such as increasing wage and income inequality will continue and that there is little or no room for more vigorous greening efforts. Muddling through puts Europe behind other nations in terms of world relevance, making it more difficult to participate in and influence others during worldwide negotiations on human rights, peace, environmental issues and trade. In contrast, a "vibrant" scenario involves more innovation, less income inequality, greater labor mobility, a selective immigration policy and increased greening. The vibrant scenario has the potential to raise happiness by focusing on reaching full employment. 
The muddling through scenario is cast in terms of innovation, employment protection legislation (EPL), taxation, social security and greening in the period 2014-2020. In contrast, a vibrant scenario contains major reforms for the driving factors of innovation (including higher education and public research), combined with substantial changes in EPL and taxation/social security, as well as in CO2 worldwide emission regulation. In this way, the vibrant scenario creates a promising foundation for full employment, less income inequality, more growth and higher sustainability.

Vibrancy in the EU is hard to imagine without adjustments in the welfare state's organization. In particular, employment protection legislation in most EU countries needs to be reconsidered. Temporary jobs have been a savior of employment, yet do not provide enough opportunities for training. EU countries should allow for more training possibilities for temporary contracts and at the same time stimulate mobility for permanent contracts. In the tradeoff with competitiveness, Europe should not lower social standards or work quality, but instead aim to generate full employment with increased labor mobility.

It is important to focus on the reduction of income inequality within and between EU countries as part of creating the vibrant scenario. There are many ways to halt rising income inequality within countries. Special attention must be paid to the working poor: some 19 million Europeans are not able to provide food or clothing for their children (European Commission 2012).

Demographics differ substantially between EU countries. Yet, the impact of the demographic transition is likely to be much less harmful to the welfare system than expected for the EU as a whole; this is due to behavioral effects such as greater labor supply with higher wages due to increased worker shortages. EU demographics should lead EU member countries to jointly devise an immigration policy based on labor market needs, in particular the need for more well-trained workers.

"Happiness" might increase in the vibrancy process, as unemployment has such a strong negative impact on the happiness of people who experience unemployment, but also on the employed.

\section{Endnote}

${ }^{1}$ Neumark (2014), among others, has argued that the minimum wage creates job losses among the unskilled without fighting poverty effectively.

Competing interests

The IZA Journal of European Labor Studies is committed to the IZA Guiding Principles of Research Integrity. The authors declare that they have observed these principles.

\footnotetext{
Acknowledgment

We wish to thank conference participants of the 2013 IZANEF Workshop: "A European Labor Market with Full Employment, More Income Security and Less Income Inequality in 2020" in Bonn for many helpful comments. Teresa Schildmann provided valuable research assistance. We are also grateful to Victoria Finn and two referees for many comments and suggestions.
}

Responsible editor: Martin Kahanec

Author details

${ }^{1}$ Maastricht University, VEF and IZA, Maastricht, Netherlands. ${ }^{2}$ IZA and Bonn University, Bonn, Germany. 


\section{References}

Acemoglu D (2002) Technical Change, Inequality, and the Labor Market. J Econ Lit 40(1):7-72

Aghion P, Howit P (2006) Appropriate growth policy: a unifying framework. J Eur Econ Assoc 4(2-3):269-314

Arni P, Eichhorst W, Pestel N, Spermann A, Zimmermann KF (2014) Kein Mindestlohn ohne unabhängige wissenschaftliche Evaluation. IZA Standpunkte No. 65, Bonn

Atkinson AB (2013) Reducing income inequality in Europe. J Eur Labor Stud 2:12

Autor DH, Levy F, Murnane RJ (2003) The skill content of recent technological change: an empirical exploration. Q J Econ 118:1279-1334

Bartelsman EJ, Gautier PA, de Wind J (2011) Employment Protection, Technology Choice, and Worker Allocation, De Nederlandsche Bank Working Paper No. 295

Boeri T (2013) Generation Indebted Jobless, IZANEF Workshop Presentation

Boeri T, Garibaldi P (2009) Beyond eurosclerosis. Econ Policy 24(59):409-461

Cahuc P, Carcillo S, Rinne U, Zimmermann KF (2013) Youth Unemployment in old europe: the polar cases of france and germany. J Eur Labor Stud 2(1):1-18.

Cedefop (2010) Skills Supply and Demand in Europe. Publications Office of the European Union, Luxembourg

Cedefop (2012) Future Skills Supply and Demand in Europe, Cedefop Research Paper No. 26

Chusseau N, Dumont M, Hellier J (2008) Explaining rising inequality: skill-biased technical change and North-South Trade. J Econ Surv 22(3):409-457

Coe DT, Helpman E, Hoffmaister AW (2009) International R\&D Spillovers and Institutions. Eur Econ Rev 53(7):723-741

Commission E (2013) Strengthening the Social Dimension of the Economic and Monetary Union. European Commission Communication, Brussels

Cooper CL, Lundberg U (2011) The Science of Occupational Health: Stress, Psychobiology, and the New World of Work. Wiley-Blackwell, Oxford

Cornell University, Insead and WIPO (2013) Innovation Index, 6th edn. URL: http://www.globalinnovationindex.org

Draeger V, Marx P (2013) Do Firms Demand Temporary Workers When They Face Production Variation? IZA Discussion Paper No. 6894

Easterlin RA (1974) Does Economic Growth Improve the Human Lot? Some Empirical Evidence. In: David PA, Reder MW (eds) Nations and Households in Economic Growth: Essays in Honor of Moses Abramovitz. Academic Press, New York

European Commission (2012) Europe's Growth Strategy: towards a job-rich recovery

European Commission (2013) European Economic Forecast, August 2013

European Parliament (2012) Towards a stronger EMU, Thyssen report

Eurostat (2013) Employment statistics

Gill I, Raiser M (2012) Golden Growth: Restoring the Lustre of the European Economic Model. World Bank, Washington DC

González F (2010) Project Europe 2030 - Challenges and Opportunities

Grabka MM, Goebel J, Schupp J (2012) Top income inequality in Germany behind us? (Höhepunkt der Einkommensungleichheit in Deutschland überschritten?). In: DIW Wochenbericht 43/2012

Gruen C, Hauser W, Rhein T (2010) Is any job better than no job? Life satisfaction and re-employment. J Lab Res 31 (3):285-306

Heckman JJ, Lochner L, Taber C (1998) Explaining rising wage inequality: explorations with a dynamic general equilibrium model of labor earnings with heterogeneous agents. Rev Econ Dyn 1:1-58

Helliwell JF, Layard R, Sachs J (eds) (2013) World Happiness Report 2013. UN Sustainable Development Solutions Network, New York

Hoareau C, Ritzen J, Marconi G (2012) The State of University Policy for Progress in Europe, IZA Policy Paper No. 51 Kolev A, Saget C (2010) Are Middle-Paid Jobs in OECD Countries Disappearing? An Overview, ILO Working Paper No. 96 Lalive R, Stutzer A (2011) Economic Shocks, Labor Market Institutions, and Workers' Well-Being. University of Lausanne. Leonardi M, Pica G (2013) Who Pays for It? The Heterogeneous Wage Effects of Employment Protection Legislation. Forthcoming.

Machin S, McNally S (2007) Tertiary Education Systems and Labour Markets. A paper commissioned by the Education and Training Policy Division, OECD, for the Thematic Review of Tertiary Education

Martin JP, Scarpetta S (2012) Setting it right: employment protection, labour reallocation and productivity. De Economist 16(2):89-116

Mazzucato M (2013) The Entrepreneurial State. Debunking Public vs Private Sector Myths. Anthem Press, London

Murphy G, Siedschlag I, Mcquinn J (2012) Employment Protection and Innovation Intensity, Neujobs Working Paper D6.4

Neumark D (2014) Employment effects of minimum wages. IZA World of Labor 2014:6, doi:10.15185/izawol.6

OECD (2008) Growing Unequal. OECD Publishing, Paris

OECD (2009) OECD Employment Outlook. OECD Publishing, Paris

OECD (2011) Divided We Stand: Why Inequality Keeps Rising. OECD Publishing, Paris

OECD (2012) OECD Economic Outlook, Volume 2012/1. OECD Publishing, Paris

OECD (2013a) Employment Outlook. OECD Publishing, Paris

OECD (2013b) How's life? 2013 Measuring Well-being. OECD Publishing, Paris

Peichl A, Dolls M, Fuest C, Neumann D, Pestel N, Siegloch S (2013) Fiscal Union in Europe? Redistributive and Stabilising Effects of a European Tax-Benefit System and Fiscal Equalisation Mechanism, IZAVEF Workshop Presentation

Putnam RD (2000) Bowling Alone. The Collapse and Revival of American Community. Simon and Schuster, New York

Rinne U, Zimmermann KF (2012) Another economic miracle? The German labor market and the great recession. J Labor Policy 2012(1):1-3.

Robertson I, Cooper C (2011) Well-Being: Productivity and Happiness at Work. Palgrave Macmillan, London

Sabia JJ, Burkhauser RV, Hansen B (2012) Are the effects of minimum wage increases always small? New evidence from a case study of New York State. Ind Labor Relat Rev 65(2):350-376

Sapir A, Aghion P, Bertola G, Hellwig M, Pisani-Ferry J, Rosati D, Viñals J, Wallace H (2003) An Agenda for a Growing Europe. Oxford University Press, Oxford 
Schneider F (2003) Zunehmende Schattenwirtschaft in Deutschland: Eine wirtschafts- und staatspolitische Herausforderung. Vierteljahrshefte zur Wirtschaftsforschung 72(1):148-159

Schneider H, Zimmermann KF (2010) Agenda 2020: Strategies to Achieve Full Employment in Germany, IZA Policy Paper 15

Soete L (2013) From Lisbon 2000 to Horizon 2020: Reflections on the Demand for Non-Routine Skills and Entrepreneurial Qualifications, IZANEF Workshop Presentation

Teulings CN (2003) The contribution of minimum wages to increasing wage inequality. Econ J 113:801-833

Tinbergen J (1975) Income Distribution: Analysis and Policies. Elsevier Science Publishing

Van Rompuy H (2012) Towards a Stronger Economic Union. European Council, Brussels

Vedder R (2003) Taxation and Migration. The Taxpayers Network, Cedarburg, WI

Vibrant Europe Forum (2012) Vaeshartelt Declaration. URL: www.vef.merit.unu.edu

Wilkinson RG (1997) Income, inequality, and social cohesion. Am J Public Health 87(9):1504-1506

World Bank (2013) Doing Business project. http://www.doingbusiness.org/

Wulfgramm M (2011) Can activating labour market policy offset the detrimental life satisfaction effect of unemployment? Soc Econ Rev 9(3):477-501

WWF (2012) Living Planet Report 2012. WWF International, Gland, Switzerland

Young C, Varner C (2012) Millionaire Migration in California: The Impact of Top Tax Rates. Stanford University.

Zimmermann KF (1995) Tackling the European migration problem. J Econ Perspect 9(2):45-62

Zimmermann KF (2005) European labour mobility: challenges and potentials. De Economist 153(4):425-450

Zoutman FT (2014) A Symphony of Redistributive Instruments. Tinbergen Institute/Thela Thesis, Amsterdam.

\subsection{6/2193-9012-3-10}

Cite this article as: Ritzen and Zimmermann: A vibrant European labor market with full employment. IZA Journal

of European Labor Studies 2014, 3:10

\section{Submit your manuscript to a SpringerOpen ${ }^{\circ}$ journal and benefit from:}

- Convenient online submission

Rigorous peer review

- Immediate publication on acceptance

- Open access: articles freely available online

- High visibility within the field

- Retaining the copyright to your article

Submit your next manuscript at $\boldsymbol{~ s p r i n g e r o p e n . c o m ~}$ 